\title{
IMPLEMENTASI NILAI-NILAI KE-NU-AN DI DESA SELOKBESUKI LUMAJANG
}

\author{
Sayyidi \\ Sekolah Menegah Kejuruan Syarifuddin Lumajang, Indonesia \\ E-mail: sayyidi.syadid@gmail.com \\ Salman Al-Farizi \\ Dinas Kearsipan dan Perpustakaan Lumajang, Indonesia \\ E-mail: sa8549772@gmail.com
}

\begin{abstract}
Abstrak: Saat semua berdebat boleh atau tidak, Nahdlatul Ulama sudah cukup alam merumuskan pikiran dan prinsip-prinsipnya. Pilihannya adalah moderat yakni perpaduan antara tawassuth, i'tidal, dan tawazun ini juga mencerminkan tradisi NU yang dalam secara kultural bersikap mempertahankan tradisi lama yang baik, menerima hal-hal baru baru yang lebih baik, tidak bersikap apriori dalam menerima salah satu di antara keduanya, dan lain sebagainya. Inilah maksud dari adagium "al-mubafazhbah 'ala al-qadim ash-shalih dan al-akhdzu bi al-jadid al-ashlah ( memelihara tradisi lama yang masib baik/ relevan dan mengambil hal-hal baru yang lebih baik)". Dengan demikian, secara konseptual NU memilih jalan moderat dan terbuka (inklusif) dalam mengamalkan ajaran agama. Lahirnya berbagai ekspresi-ekspresi ritual yang nilai instrumentalnya produk budaya lokal, sedangkan muatan materialnya bernuansa religius Islam adalah sesuatu yang wajar dan sah adanya dengan syarat akulturasi tersebut tidak menghilangkan nilai fundamental dari ajaran agama. Lokasi penelitian adalah Desa Selokbesuki Lumajang. Kesimpulan dari penelitian ini adalah keteguhan masyarakat untuk tetap menjalankan tradisinya sesuai dengan prinsip dan ajaran Ahlussunnah Wal Jamaah.
\end{abstract}

Kata kunci: Implementasi dan Nilai-Nilai Ke-NU-an

\section{Pendahuluan}

Ahlus Sunnah wal Jama'ah menurut KH. Hasyim Asy'ari yang dikutip oleh Lathiful Khuluq adalah ulama' dalam bidang tafsir al-Qur'an, Sunnah Rasul dan Fiqih yang tunduk pada tradisi Rasul dan Khulafaur Rasyidin. Selanjutnya beliau menyatakan bahwa ulama' tersebut sampai sekarang adalah mereka yang mengikuti mazhab Maliki, Hanafi, Syafi'i dan Hambali. ${ }^{1}$

Salah satu ormas keagamaan yang kemudian menformulasikan ajaran ASWAJA sebagai dasar ajaran agamanya adalah Nahdhatul Ulama (NU). Nahdlatul Ulama' (NU) adalah sebuah organisasi kemasyarakatan (ormas) Islam terbesar di Indonesia bahkan di dunia. NU termasuk ormas yang tua di Indonesia, didirikan pada 31 Januari 1926 M. sebagai faham keagamaan, NU sebenarnya sudah berusia ratusan tahun, setua usia Islam di Indonesia. NU sebagai ajaran biasa disebut NU kultural, yaitu penganut ajaran Ahlussunnah wa al-Jama'ah (Aswaja). ${ }^{2}$

Kerangka pemahaman keagamaan ASWAJA yang dikembangkan NU memiliki karakteristik khusus yang mungkin juga membedakan dengan kelompok muslim lainya yaitu berporos pada

\footnotetext{
${ }^{1}$ Lathiful Khuluq, Fajar Kebangunan Ulama, Biografi KH. Hasyim Asy'ari (Yogyakarta: LKiS, 2000), 46.

${ }^{2}$ Salahuddin Wahid, Dkk. Menggagas NU Masa Depan (Jombang: Pustaka Tebuireng, 2010), 1. 
tiga pilar ajaran pokok dalam Islam yang meliputi bidang Aqidah, Fiqh dan Tasawwuf. ${ }^{3}$ Di bidang Aqidah, model yang diikuti oleh NU adalah pemikiran-pemikiran aqidah yang dikembangkan oleh Abu Hasan al-'Asy'ari dan Abu Mansur al-Maturidi. Pada bidang Figh, mengikuti model pemikiran dan metode istimbat hukum yang dikembangkan empat imam madzhab (aimmat almadzabib al-arba'ab) yaitu madzhab Hanafi, Maliki, Syafi'i dan Hanbali. Sedangkan dibidang Tasawwuf mengikuti model yang dikembangkan oleh Abu Hamid al-Ghazali dan Al-Juwaini alBaghdadi.

Pemahaman tentang paham Ahlus Sunnah wal Jama'ah sangat penting bagi warga NU, Karena Aswaja merupakan fundamen NU dalam membangun gerakan dan berkhidmat kepada umat. Dengan sendirinya seluruh metode berpikir (manhaj al-fikri) dan metode pergerakan (manhaj al-haraki) warga, terutama pengurus NU dan lembaga di bawahnya, harus merujuk kepada konsep dan semangat Aswaja.

Peristiwa berdirinya Nahdlatul Ulama (NU) tidak terlepas dari beberapa organisasi yang dibentuk oleh para tokoh NU, seperti Nahdlatut Tujjar (kebangkitan para pedagang) tahun 1918 sebagai gerakan ekonomi pedesaan, Tashwirul Afkar (forum diskusi) tahun 1922 sebagai gerakan keilmuan dan kebudayaan, dan Nahdlatul Wathan (kebangkitan tanah air) sebagai gerakan politik dalam pendidikan. ${ }^{4}$ Dengan terbentuknya organisasi ini, maka pada akhirnya terbentuklah juga sebuah organisasi besar yang mewadahi para ulama dan kalangan tradisionalis (pesantren). Tepatnya pada tanggal 31 Januari 1926 M atau 16 Rajab 1344 H., para ulama terkemuka berkumpul di Surabaya untuk mendirikan sebuah organisasi yang kemudian diberi nama Jamiyah Nahdlatul Ulama (NU). Inilah salah satu perjalanan dan proses NU berdiri, dengan harapan untuk mempertahankan dan memperjuangkan ajaran Islam ahlussunnah wal jama'ah (Aswaja).

Madzhab Ahl al-Sunnah wa al-Jama'ah dalam pandangan NU merupakan pendekatan yang multidimensional dari sebuah gagasan konfigurasi aspek aqidah, fiqh dan tasawwuf. Ketiganya merupakan satu kesatuan yang utuh, masing-masing tidak terpilah dalam trikotomi yang berlawanan. Hanya saja dalam prakteknya, dimensi ajaran fiqh (hukum Islam) jauh lebih dominan dibanding dimensi yang lain.

Dalam pemikiran figh yang dianut NU konsep hukum Allah terbagi menjadi dua besaran yaitu hukum yang bersifat iqtidha (sesuatu yang sudah ada ketentuanya secara eksplisit dalam nash) dan hukum Allah yang bersifat takhyir (belum ada ketentuan dasarnya) yang biasanya disebut ibahah. Ketentuan hukum yang secara eksplisit tidak diatur jumlahnya jauh lebih banyak dan ini merupakan wilayah hukum yang bersifat ijtihadiyah dan menjadi tugas umat Islam untuk

\footnotetext{
${ }^{3}$ As'ad Said Ali, Pergolakan di Jantung Tradisi (Jakarta: LP3ES, 2008), 37.

${ }^{4}$ Ali Maschan Moesa, Memabami Nabdlatul Ulama: Urgensi Besar Membangun Kembali Jembatan Putus (Surabaya: Pesantren Luhur Al-Husna, 2010), 5.

96 | Tarbiyatuna: Jurnal Pendidikan Islam; Volume 13, Nomor 1, Februari 2020 
megembangkanya dengan mendasarkan pada kaidah fiqh al-Hukmu ma'a al-Illat (hukum itu didasarkan pada ada dan tidaknya alasan hukum yang mendasarinya) dengan mendasarkan pada logika sebab akibat (causality) yang biasanya mendasarkan pada kalkulasi maslahat dan madharat.

Formulasi pemahaman keagamaan NU terhadap ASWAJA yang mengikuti pola/model ulama mazdhab bukan berarti NU puas dengan situasi Jumud/ stagnan yang penuh taqlid sebagaimana dituduhkan oleh kelompok "Islam Modernis". Ide dasar pelestarian mazdhab oleh NU justru sebagai bagian dari tanggung jawab pelestarian dan pemurnian ajaran Islam itu sendiri. Pola bermazdhab yang dikembangkan oleh NU sebagaimana hasil Musyawarah Nasional di Bandar Lampung tahun 1992 menganut dua pola yaitu bermazdhab secara qauli (tekstual) ataupun bermazdhab secara manhaji (dimensi metodologis/ istinbathi). Tetapi, menurut pandangan NU, bukan berarti Aswaja dan "ber-mazhab", kita diharuskan langsung untuk memahami dan menerapkan ajaran yang terkandung dalam al-Quran dan al-Hadits, tanpa mempertimbangkan bagaimana zaman yang selalu berubah, bagaimana cara menghukumi sesuatu yang tidak ada dalilnya yang sharih (jelas) di dalam al-Quran dan al-Hadits, dan masalah-masalah sosial lainnya, yang juga tidak pernah ada dalam al-Quran dan al-Hadits.

Watak atau ciri NU dalam mengembangkan paham Ahlussunnah Waljama'ah adalah pengambilan jalan tengah yang berada di antara dua ekstrem. Kalau kita melihat ke belakang, sejarah teologi Islam memang banyak diwarnai oleh berbagai macam ekstrem, seperti Khawarij dengan teori pengkafirannya terhadap pelaku dosa besar, Qadariyah dengan teori kebebasan kehendak manusianya, Jabariyah dengan teori keterpaksaan kehendak dan berbuat manusianya, dan Muktazilah dengan pendewaannya terhadap kemampuan akal dalam mencari sumber ajaran Islam. Di sinilah Asy'ariah dan Maturidiah, dengan mengambil inspirasi berbagai pendapat yang sebelumnya dikembangkan terutama oleh Ahmad ibn Hanbal, merumuskan formulasi pemahaman kalamnya tersendiri dan banyak mendapatkan banyak pengikut di seluruh dunia. ${ }^{5}$

Paham Ahlussunnah Wal jama'ah memiliki karakter sebagai berikut: Pertama, tawasuth atau sikap moderat dalam seluruh aspek kehidupan. Kedua, al-i'tidal atau bersikap tegak lurus dan selalu condong pada keberanaran keadilan, ketiga, al-tawazun atau sikap keseimbangan dan penuh pertimbangan dan ke-empat, rahmatan lil'alamin, yaitu mensejahterakan seluruh alam semesta. Karakter tersebut berfungsi untuk menghindari tatharruf atau sikap ekstrim dalam segala aspek kehidupan. Dengan kata lain, harus ada pertengahan dan keseimbangan dalam berbagai hal. Dalam akidah, misalnya, harus ada keseimbangan atau (pertengahan) antara penggunaan dalil naqliy dan 'aqliy, antara ekstrim Jabariyah dan Qadariyah. Dalam bidang syari'ah dan fikih, ada pertengahan antara ijtihad "sembrono" dengan taqlid buta dengan jalan bermazhab. Tegas dalam

5 Zuhairi Misrawi, Hadratussyaikh Hasyim Asy'ari Moderasi, Keummatan dan Kebangsaan (Jakarta: PT. Kompas Media Nusantara, 2010), 140. 
hal-hal qath'iyyat dan toleran pada hal-hal dzanniyyat. Dalam akhlak, ada keseimbangan dan pertengahan antara sikap berani (syaja'ah) dan sikap penakut serta "ngawur". Sikap tawadlu' (rendah hati) merupakan pertengahan antara takabbur (sombong) dan tadzallul (rendah diri). ${ }^{6}$

Secara keseluruhan, bisa juga dikatakan bahwa paham keagamaan Ahlussunah Wa alJama'ah yang ditampilkan oleh NU merupakan manhaj yang mengambil jalan tengah antara kaum ekstrem 'aqliy (rasionalis) dengan kaum ekstrem naqliy (skripturalis). Akan tetapi, dalil-dalil berdasarkan nash al-Qur'an dan sunnah (naqliy) secara hierarkis berada di atas dalil berdasarkan akal atau logika (aqliy). Dengan kata lain bahwa di dalam lingkungan NU diterapkan metode berpikir untuk mendahulukan nash dari pada akal (taqdim an-nashsh 'ala al-aq). ${ }^{7}$

Dalam tataran implementasi, memang selalu ditemukan kendala antara sisi al-mubafą̧bah 'ala al-qadimi ash-shalih dan al-akhdzu bi al-jadid al-ashlah. Yaitu, adanya kesimpulan bahwa kaum nahdliyyin merupakan masyarakat Islam tradisional, pada satu sisi barangkali -meskipun bisa dipahami dalam pengertian lain, antusiasme mereka dalam melestarikan budaya dan tradisi lokal dalam mengamalkan ajaran agama disebabkan oleh kenyataan bahwa dalam mengimplementasikan paham Ahlussunnah Wa al-Jama'ah itu mereka lebih menitikberatkan pada aspek prinsip tadi.

Aktualisasi sebuah ajaran tentu mensyaratkan adanya upaya untuk selalu menjadikan ajaran itu relevan dengan situasi kongkret dan kekinian, serta mampu memberikan solusi atas persoalanpersoalan yang terus berkembang. Hal ini mengandaikan adanya proses pencermatan secara kritis terhadap apa yang telah dihasilkan oleh para pendiri paham Ahlussunah Wa al-Jama'ah. Sikap yang cermat dan kritis inilah yang akan mengantarkan seseorang bersikap moderat dan terbuka dalam beragama.

Dalam kehidupan, tidak bisa dipisahkan dari yang namanya budaya, karena budaya adalah kreasi manusia untuk memenuhi kebutuhan dalam memperbaiki kualitas hidupnya. Salah satu karakter dasar dari setiap budaya adalah perubahan yang terus-menerus sebagaimana kehidupan itu sendiri. Proses dialektika Islam dengan budaya lokal Indonesia yang menghasilkan produk budaya sintetis merupakan suatu keniscayaan sejarah sebagai hasil dialog Islam dengan sistem budaya lokal. Lahirnya berbagai ekspresi-ekspresi ritual yang nilai instrumentalnya produk budaya lokal, sedangkan muatan materialnya bernuansa religius Islam adalah sesuatu yang wajar dan sah adanya dengan syarat akulturasi tersebut tidak menghilangkan nilai fundamental dari ajaran agama.

\footnotetext{
${ }^{6}$ Achmad Shiddiq, Khittah Nabdliyyah (Surabaya: Balai Buku, 1980), 12.

${ }^{7}$ Eka Putra Wirman, Kekuatan Ablussunnah Wa al-Jama'ah (Jakarta: Badan Litbang dan Diklat Kementrian Agama RI, 2010), 86. 
NU memiliki karakter memadukan tradisi ulama salaf dengan tradisi kebudayaan lokal. NU juga memiliki sejumlah tradisi yang khas, seperti tahlilan, dibaan dan ziarah kubur yang hal tersebut dilarang oleh kelompok muslim lain. ${ }^{8}$ Hal tersebut berdasarkan sebuah kaidah:

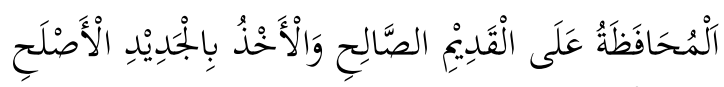

Artinya : memelihara tradisi lama yang masih baik (relevan) dan mengambil hal-hal baru yang lebih baik."

Hal di atas, dibenarkan oleh KH. Hasyim Asy'ari, sebab ASWAJA adalah kelompok yang mengikuti tradisi orang-orang shaleh di masa lalu (al-salaf al-shalih). Mereka adalah orang-orang yang mengikuti ulama dari dua kota suci (Mekkah dan Madinah) serta para ulama dari al-Azhar, Kairo dan Mesir. ${ }^{10}$

Basis sosial warga NU adalah masyarakat muslim yang secara keagamaan pada umumnya berbasis pendidikan pesantren baik masyarakat pedesaan maupun perkotaan, walaupun sekarang ini terjadi pergeseran yang sangat signifikan pada tataran segmen warga NU dengan lahirnya alumni-alumni perguruan tinggi baik dalam maupun luar negeri.

Salah satu desa di Lumajang yang mayoritas masyarakatnya Nabdliyyin (pengikut NU) adalah desa Selokbesuki Sukodono Lumajang. Pendidikan, amaliyah dan ritual keagamaan NU tetap dipertahankan, karena ritual-ritual dan amaliyah yang bercorak lokal tersebut hanyalah sebatas teknis atau bentuk luaran saja, sedangkan yang menjadi subtansi di dalamnya murni ajaran-ajaran Islam. Dengan kata lain, ritual-ritual yang bercorak tradisi lokal hanyalah bungkus luar, sedangkan isinya adalah nilai-nilai ibadah yang diajarkan oleh Islam. Sebagai contoh, ritual selamatan atau kenduri yang dilakukan dengan ceremonial pada waktu-waktu tertentu sesuai dengan kebiasaan lokal yang berlaku, didalamnya diisi dengan ibadah-ibadah yang dianjurkan Islam seperti bersedekah, dzikir, berdo`a, membaca al-Qur`an dan lain sebagainya. Mengenai ceremonial atau penentuan waktu tersebut, tidak lebih hanyalah kemasan luar sebagai bentuk penyesuaian dengan teknis dan kebiasaan yang berlaku ditengah masyarakat dan tidak bertentangan dengan ajaran Islam. Karena itu, pertanyaan untuk dijadikan rumusan dalam riset ini antara lain bagaimana implementasi nilai-nilai Ke-NU-an di Desa Selokbesuki Kecamatan Sukodono Kabupaten Lumajang dan apa saja kendalanya.

\section{Metodologi}

Penelitian ini menggunakan pendekatan kualitatif. Metode kualitatif ini digunakan karena beberapa pertimbangan pertama, menyesuaikan metode kualitatif lebih mudah apabila berhadapan dengan kenyataan ganda, kedua, metode ini menyajikan secara langsung hakikat

\footnotetext{
${ }^{8}$ Zuhairi, Hadratussyaikh, 108.

${ }^{9}$ Sahal Mahfudh, Nuansa Fiqib Sosial (Yogyakarta: LKiS, 2004). 5.

10 Zuhairi, Hadratussyaikh, 109.
} 
hubungan antara peneliti dan responden, dan ketiga, metode ini lebih peka dan lebih mudah menyesuaikan diri dengan banyak penajaman pengaruh bersama dan terhadap pola-pola nilai yang di hadapi.

\section{Dinamika Tradisi dan Nilai Keagamaan}

Penduduk Nusantara sebelum Islam datang sudah memiliki kepercayaan, yaitu animisme, dinamisme, Hindu, Dan Budha. Pada zaman itu penduduk Indonesia dalam melaksanakan kepercayaannya menggunakan seni sebagai bentuk upacaranya. Melihat kenyataan di masyarakat nusantara seperti itu maka para da’i (penyebar agama Islam) menggunakan strategi dakwahnya melalui seni dan budaya upacara mereka. Tujuannya supaya agama Islam dapat dengan mudah diterima oleh mereka berdasarkan adat budayanya tanpa menghilangkan adat upacara sesuai dengan agama dan kepercayaan. Dengan demikian seni budaya dan upacara adat nusantara masih tetap lestari dan berkembang sampai sekarang dan jauh dari unsur syirik atau menyimpang dari ajaran agama Islam, salah satunya tradisi keagamaan yang masih dilakukan di desa Selokbesuki Sukodono Lumajang.

Kegiatan keagamaan di desa Selokbesuki sama seperti kegiatan keagamaan masyarakat di desa-desa lainnya. Sebagaimana yang dijelaskan oleh bapak Maimun selaku Kepala Desa Selokbesuki, "kegiatan keagamaan yang dilakukan masyarakat disini sama dengan kegiatan keagamaan yang dilakukan oleh masyarakat di desa-desa lainnya, karena itu sudah menjadi tradisi yang tidak akan bisa hilang. Salah satu kegiatan tersebut adalah Tahlilan, Selamatan, Tasyakkuran, rutinan pengajian dan sholawatan". ${ }^{11}$

Memperkuat penjelasan diatas, peneliti juga silaturrahim kepada Ahmad Ubaidillah selaku Kaur Pemerintahan sekaligus Sekretaris NU disana, beliau juga menambahkan, bahwa "Nilai-nilai atau tradisi NU yang dilakukan di desa Selokbesuki diantaranya adalah Selamatan, Merawat Janazah, Tawassul, Tahlilan, Maulidan, Qunnut Shubuh, Dzikir/Wiridan dan Sholat Tarawikh 20 roka'at pada bulan Ramadlan. ${ }^{12}$

Mengenai sejak kapan dilakukan hal tersebut, peneliti silaturrahim kepada H. Busiri (selaku tokoh masyarakat Dusun Krajan Wetan), beliau juga menambahkan bahwa:

"tradisi di desa Selokbesuki yang dilakukan sampai saat ini adalah Selamatan, Sholawatan, membaca Surat Yasin, mensholati Mayyit, Talqin Mayyit, Adzan 2 kali waktu Sholat Jum'at, wirid dan sebagainya yang merupakan tradisi-tradisi NU. Mengenai kapan dimulainya tradisi-tradisi di atas, tidak dapat dijelaskan secara detail, karena hal tersebut sudah turuntemurun yang telah dilakukan oleh para sesepuh/pendahulu kita. Namun jika menoleh kepada sejarah Walisongo, mungkin pada masa merekalah tradisi ini dimulai, karena mereka adalah penyebar Islam di Pulau Jawa dengan memasukkan nilai-nilai Islam ke dalam seni

\footnotetext{
${ }^{11}$ Maimun, Wawancara, Lumajang, 25 Mei 2016.

12 Ahmad Ubaidillah, Wawancara, Lumajang, 25 Mei 2016.

100 | Tarbiyatuna: Jurnal Pendidikan Islam; Volume 13, Nomor 1, Februari 2020 p-ISSN: 2085-6539; e-ISSN: 2242-4579
} 
budaya dan adat yang ada. Terkadang ada sebagian warga yang hanya imitatif (ikut-ikutan) saja". ${ }^{13}$

Berdasarkan wawancara di atas, peneliti hadir bersama masyarakat untuk melihat tradisi keagamaan di desa Selokbesuki tersebut, diantaranya adalah Tahlilan, Maulid Nabi, Tarawih 20 roka'at, dan Qunut. Sedangkan pelaksanaan kegiatan-kegiatan tersebut dijelaskan dalam pembahasan berikut.

\section{Tahlil}

Telah kita maklumi bersama bahwa acara tahlilan merupakan upacara ritual seremonial yang biasa dilakukan oleh keumuman masyarakat Indonesia untuk memperingati hari kematian. Secara bersama-sama, beserta masyarakat sekitarnya, membaca beberapa ayat al-Quran, dzikirdzikir, dan disertai doa-doa tertentu untuk dikirimkan kepada mayyit. Acara ini biasanya diselenggarakan setelah selesai proses penguburan (terkadang dilakukan sebelum penguburan mayyit), kemudian terus berlangsung setiap hari sampai hari ketujuh. Lalu diselenggarakan kembali pada hari ke 40 dan ke 100 serta ke-1000. Untuk selanjutnya acara tersebut diadakan setiap tahun dari hari kematian mayyit, walaupun terkadang berbeda antara satu tempat dengan tempat lainnya.

Mengenai hal ini, Ahmad Ubaidillah memberikan penjelasan mengenai kegiatan tahlilan di desa Selokbesuki, beliau mengatakan bahwa:

"acara tahlilan sudah biasa dilakukan, baik di desa ini maupun di desa-desa lain, ketika ada orang yang meninggal dan orang tersebut merupakan orang Islam. Tahlilan biasanya dilaksanakan setiap ada orang yang meninggal sejak hari pertama meninggal sampai 40 hari, hari ke-100, setahun, 2 tahun dan 1000 hari. pelaksanaannya dimulai setelah sholat Maghrib dan ada juga setelah sholat Isya'.

Sedangkan yang dibaca adalah surat Yasin, ayat-ayat al-Qur'an dan sholawat pada Nabi serta do'a". ${ }^{14}$ Maulana warga desa Selokbesuki mengatakan:

“Terkadang masyarakat juga mengadakan Khotmil Qur'an sebelum pelaksanaan Tahlil. Masyarakat menyebut hal tersebut sebagai kirim-kirim do'a/pahala kepada orang yang sudah meninggal. Khotmil Qur'an juga dilakukan saat acara Selamatan, baik pernikahan maupun hajjian.

Rutinan Yasinan yang dikemas dengan arisan pun juga membaca tahlil (setelah baca surat Yasin). Rutinan ini biasanya dilaksanakan di setiap RW. satu minggu sekali. Ada yang malam Jum'at, malam senin dan sebagainya. Setelah pembacaan ayat-ayat dan sholawat selesai, barulah arisan diselenggarakan (dikocok). Barang siapa yang mendapat arisan (namanya keluar pada waktu dikocok), rumah orang tersebut yang nantinya menjadi tempat berkumpul yang berikutnya". ${ }^{15}$

\footnotetext{
${ }^{13}$ Busiri, Wawancara, Lumajang, 25 Mei 2016.

${ }^{14}$ Ahmad Ubaidillah, Wawancara, Lumajang, 25 Mei 2016.

15 Maulana, Wawancara, Lumajang, 25 Mei 2016.
} 
Lebih jelasnya lagi, peneliti berkunjung kepada salah satu warga Selokbesuki bernama Untung. Saat beliau ditanya tentang hal ini, beliau menjawab :

"mayoritas masyarakat desa Selokbesuki merupakan warga NU. Ketika ada orang meninggal maka akan ditahlili, meskipun orang yang mati adalah warga Muhammadiyah. Tidak ada konflik antara kaum NU dan Muhammadiyah mengenai Tahlilan (Doktrin "Tahlilan tradisi NU bukan Muhammadiyah"). Hal ini pernah terjadi pada al-Marhum Mulyono RT. IV RW. I Dusun Krajan Kulon. Keluarga beliau(warga Muhammadiyah) tidak mengomentari hal tersebut karena menganggap Tahlilan sebagai kultur desa". ${ }^{16}$

Setelah itu peneliti berbincang-bincang lagi dengan Ubaidillah, ia mengatakan :

"Entah telah berapa abad lamanya acara tersebut diselenggarakan, hingga tanpa disadari menjadi suatu kelaziman. Konsekuensinya, bila ada yang tidak menyelenggarakan acara tersebut, berarti ia telah menyalahi adat, dan akibatnya ia diasingkan oleh masyarakat. Bahkan lebih jauh lagi, acara tersebut telah membangun opini muatan hukum yaitu sunnah atau wajib untuk dikerjakan dan sebaliknya, bid'ah (hal yang baru dan ajaib) apabila ditinggalkan. العادة محكّمه (tradisi dijadikan sebuah hukum). ${ }^{17}$

Berdasarkan hasil wawancara di atas yang peneliti lakukan di lapangan, acara tahlilan merupakan tradisi warga desa Selokbesuki yang dilakukan ketika:

1. ada orang Islam yang meninggal (tanpa memandang status mayyit itu NU atau Muhammadiyah), mulai hari pertama sampai tujuh (7) hari berturut-turut, hari ke-40, hari ke100 dan hari ke-1000 meninggalnya mayyit,

2. Rutinan mingguan

3. juga biasa dikemas dengan arisan dan Khotmil Qur'an.

Sedangkan pelaksanaannya setelah sholat Isya', sebagian dilaksanakan setelah Maghrib bahkan 'Ashar. Dan acara ini dimulai dengan membaca surat Yasin, ayat-ayat al-Qur'an dan sholawat pada Nabi.

\section{Maulid Nabi}

Nabi Muhammad adalah Nabi akhir zaman yang selalu menjadi panutan yang tidak akan pernah ada yang mengingkari kebenarannya. Beliaulah yang menuntun umat manusia menuju jalan yang terang benderang dengan selalu disinari cahaya Islam. Dengan perjuangan beliau umat manusia bangkit dari zaman jahiliyah menuju zaman yang terang dengan cahaya Islam. Dengan kelahiran Nabi akhir zaman ini terciptalah aturan-aturan Islam yang penuh keharmonisan, persaudaraan, dan keseimbangan dengan terhapusnya perselisihan, pertikaian, dan peperangan.

Betapa luar biasa jasa Nabi Muhammad SAW kepada seluruh umat manusia yang ada di dunia ini. Maka sudah sepantasnya kita sebagai umatnya untuk selalu mengenangnya dan berusaha sekuat tenaga untuk mengamalkan apa yang telah diajarkan oleh beliau. Karena apa yang telah dikatakan, dilakukan, dan ditetapkan beliau telah menjadi dasar segala hukum Islam setelah $\mathrm{Al}$ -

${ }^{16}$ Untung, Wawancara, Lumajang, 25 Mei 2016.

17 Ahmad Ubaidillah, Wawancara, Lumajang, 25 Mei 2016.

102 | Tarbiyatuna: Jurnal Pendidikan Islam; Volume 13, Nomor 1, Februari 2020 p-ISSN: 2085-6539; e-ISSN: 2242-4579 
Qur'an yang sudah tidak diragukan kebenarannya. Karena dengan mengikuti apa yang telah diajarkan oleh beliau kepada kita, maka kita akan diakui sebagai umat beliau kelak di Hari Kiamat.

Mengenai perayaan hari kelahiran Nabi dan Sholawatan di desa Selokbesuki, peneliti pertama kali silaturrahim kepada Maimun selaku Kepala Desa Selokbesuki, beliau memberikan penjelasan SAW., bahwa

"Masyarakat sangat antusias dalam merayakan hal tersebut, terlihat di mushollamusholla, rumah-rumah, masjid dan di lembaga-lembaga pendidikan. Perayaan ini biasanya dikemas dengan membaca Sholawat kepada Nabi. Hal tersebut dilakukan sebagai bentuk kecintaan dan ingin mendapatkan syafa'at Nabi fii yawmi al-qiyamah. Perayaan Maulid Nabi ini dilaksanakan pada 12-19 Robi'ul Awal". ${ }^{18}$

Peneliti juga menanyakan hal tersebut kepada Maulana, ia juga menambahkan bahwa :

"perayaan Maulid Nabi yang meriah tepat pada malam tanggal 12 Robi'ul Awal. Masyarakat berkumpul di masjid dan musholla-musholla dekat rumahnya. Terkadang pelaksanaan ini dilakukan dari rumah ke rumah (secara pribadi dengan mengundang tetangga dan saudara) meski sederhana, sampai akhir bulan. Perayaan hari kelahiran Nabi merupakan bentuk kecintaan dan penghormatan pada Nabi dengan membaca Sholawat pada nabi dan Barzanjen. Bersholawat tidak hanya dilakukan pada saat memperingati Hari Kelahiran Nabi, namun juga setiap hari karena ingin mendapatkan syafa'atnya besok di hari Qiyamat. Seperti rutinan-rutinan yang dilakukan masyarakat dengan membaca Barzanjen, Maulid Habsyi, serta berupa Hadrah seperti al-Banjari. ". ${ }^{19}$

Mengenai alasannya pelaksanaan hal tersebut, peneliti mendatangi Ubaidillah, beliau berpedoman pada :

1. Hadist

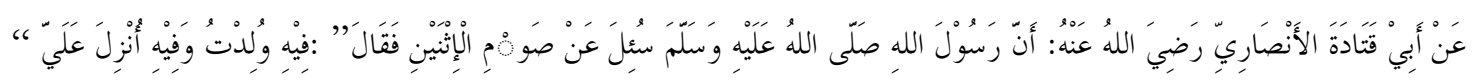

Artinya: Dari Abi Qotadah al-Anshori, sesunggubnya Rasulullah SAW pernah ditanya mengenai puasa hari senin. Rasulullah menjawab: Pada hari itu aku dilabirkan dan wahyu diturunkan kepadaku.

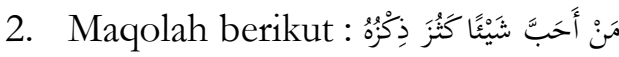

Artinya : Barang siapa yang mencintai sesuatu, ia akan sering menyebutnya."

"Pola areyah dalilleh (bahasa Madura). Rasulullah saja memperingati kelahirannya, apalagi kita selaku ummatnya sebagai bentuk kecintaan kita kepadanya. Salah satu untuk menunjukkan cinta kita kepada Nabi Muhammad SAW. adalah dengan mengenang kelahiran beliau. Maulid Nabi merupakan bentuk penghargaan yang sangat besar kepada beliau dan kita harus bangga memiliki hari besar ini. Dengan terlaksananya kegiatan ini semoga menjadikan motivasi dan inspirasi kecintaan kita kepada Nabi Muhammad SAW dan selalu menjalankan sunnahsunnahnya". ${ }^{20}$

Mengenai model pelaksanaan maulid Nabi yang dilakukan di desa Selokbesuki, Umarul Faruq menjelaskan bahwa:

"ketika perayaan maulid Nabi tiba (12 Robi'ul Awal), masyarakat sangat antusias menyambutnya dengan menghiasi/meramaikan Masjid, Musholla dan tempat lainnya

\footnotetext{
18 Maimun, Wawancara, Lumajang, 25 Mei 2016.

${ }^{19}$ Maulana, Wawancara, Lumajang, 25 Mei 2016.

20 Ahmad Ubaidillah, Wawancara, Lumajang, 25 Mei 2016.
} 
yang digunakan sebagai tempat perayaan maulid tersebut. Pada umumnya, masyarakat berkumpul ditempat perayaan tersebut dengan membawa Nasi, Buah dan lainnya yang dapat memeriahkan acara maulid tersebut". ${ }^{21}$

dasarkan hasil wawancara di atas yang peneliti lakukan di lapangan, perayaan Maulid Nabi Muhammad SAW. sebagai bentuk kecintaan pada Nabi di desa Selokbesuki dilaksanakan pada malam tanggal 12 Robi'ul Awal di masjid dan musholla setelah sholat Maghrib dengan membaca Diba'iyah dan Asyraqal. Sedangkan pelaksanaan yang dikemas dengan mendatangkan al-Banjari serta pengajian umum dilaksanakan setelah sholat Isya' bertempat di balai desa dan tempat-tempat lainnya.

\section{Qunut Shubuh}

Persoalan membaca do'a qunut pada shalat shubuh ketika i’tidal kedua, merupakan perselisihan fiqih sejak dulu. Ini termasuk perselisihan yang paling banyak menyita waktu, tenaga, pikiran, bahkan sampai memecahkan barisan kaum muslimin. Namun hal ini merupakan praktik keagamaan yang dilakukan oleh warga nabdliyyin sebagaimana yang dilakukan oleh warga desa Selokbesuki.

Dalam hal ini, peneliti menemui Ach. Zaini, ia mengatakan bahwa "pelaksanaan Sholat Shubuh disini, masyarakat melaksanakannya dengan qunnut. Hal tersebut dapat dilihat di setiap musholla atau masjid di desa Selokbesuki. Pelaksanaan ini sudah menjadi kultur. Seandainya ada masjid atau musholla yang tidak melaksanakannya, kemungkinan akan menjadi sebuah pembicaraan masyarakat luas". ${ }^{22}$

Kemudian Ach. Zaini agar mengatakan sebagai berikut:

"qunnut Shubuh ini merupakan Sunnah 'Ab'ad (apabila meninggalkan, maka harus mengganti dengan Sujud Sahwi). Itulah yang diajarkan oleh para kiai, tokoh masyarakat dan guru-guru yang notabene adalah santri. Di desa Selokbesuki ini, mayoritas masyarakatnya adalah NU, sudah tentu sholat Shubuhnya disertai qunnut meskipun ada sebagian warga yang hanya ikut-ikutan saja. Dan ada hadits yang menjadi dasar, yaitu:

$$
\text { عن أنس بن مالك قال مازال رسول الله يقنت في الفجر حتّى فارق الدنيا (رواه أحمد) }
$$

Artinya: "Diriwayatkan dari Anas Ibni Malik, beliau berkata "Rasulullah SAW. senantiasa membaca qunut ketika sholat shubuh sampai beliau wafat". (HR. Abmad, 12196)". ${ }^{23}$

Sedangkan bacaan qunut Shubuh yang biasa dibaca di desa selokbesuki menurut H. Busiri adalah sebagai berikut: ${ }^{24}$

\footnotetext{
${ }^{21}$ Umarul Faruq, Wawancara, Lumajang, 4 Juli 2016.

${ }^{22}$ Ach. Zaini, Wawancara, Lumajang, 25 Mei 2016.

${ }^{23}$ Ach. Zaini, Wawancara, Lumajang, 25 Mei 2016.

${ }^{24}$ Busiri, Wawancara, Lumajang, 25 Mei 2016.

104 | Tarbiyatuna: Jurnal Pendidikan Islam; Volume 13, Nomor 1, Februari 2020 p-ISSN: 2085-6539; e-ISSN: 2242-4579
} 


$$
\begin{aligned}
& \text { اللهم اهدنا فيمن هديت, وعافينا فيمن عافيت, وتولنا فيمن توليت, وبارك لنا فيما أعطيت, وقنا شرما } \\
& \text { قضيت, فإنك تقضي ولابقضى عليك, وإنه لايذل من واليت,ولايعز من عاديت,تباركت ربنا } \\
& \text { وتعاليت,فلك الحمد على ما قضيت, نستغفرك ونتوب إليك }
\end{aligned}
$$

Berdasarkan hasil wawancara di atas yang peneliti lakukan di lapangan, pelaksanaan qunut sholat Shubuh di desa Selokbesuki dilakukan setelah i'tidal pada raka'at kedua. Hal tersebut peneliti amati di beberapa musholla di desa Selokbesuki, diantaranya adalah musholla ustadz Syafi'i dan ustadz Rahmad.

\section{Sholat Tarawikh}

Shalat Sunnah Tarawih merupakan shalat sunnah yangg dikerjakan di malam hari setelah Shalat Isya' di Setiap bulan Ramadlan yang merupakan bulan penuh berkah. Untuk Hukum Mengerjakan Shalat Tarawih sendiri ialah Sunnah Muakkad yang bisa diartikan Sunnah yang sangat diutamakan atau diharuskan untuk dikerjakan setiap umat Muslim di seluruh dunia karena Shalat Sunnah Tarawih bisa menjadi pelengkap puasa kita.

Sedangkan Jumlah Rakaat Shalat Tarawih ini masih diperselisihkan, ada yang mengatakan 8 raka'at dan bisa berjumlah 20 raka'at. Namun di Indonesia, mayoritas jumlah raka'at Shalat Tarawih yang dikerjakan ialah 20 Raka'at dan ditambah 3 raka'at Witir di akhir Shalat Tarawih. Cara Shalat Tarawih sendiri lebih baik dikerjakan secara berjamaah walaupun jika dikerjakan sendiri pun masih boleh.

Pelaksanaan sholat tarawih di desa Selokbesuki adalah 20 raka'at, sebagaimana yang dikatakan Gus Rahmad, bahwa

“Sholat Tarawikh, Masyarakat melaksanakannya 20 Roka'at (2 raka'at salam), 3 Roka'at witir (yang pertama 2 Roka'at kemudian salam, 1 raka'at dan salam) dan qunnut pada separuh akhir Ramadlan (malam 16 Ramadlan). Hal itu dilakukan pada setiap bulan Ramadlan, disetiap musholla dan masjid di desa Selokbesuki”. Alasannya adalah Hadits berikut :

عن يزيد بن رومان أنّه قال كان الناس يقومون في زمان عمر بن الخطاب في رمضان بثلاث وعشرين ركعة (رواه مالك) Artinya : Dari Yazid bin Ruman, ia berkata, "orang-orang muslimin pada masa Umar bin Khaththab melakukan sholat malam di bulan Ramadlan 23 raka'at". (HR. Malik dalam Muwaththa, 233)."25

Kemudian peneliti juga menemui Ahmad Ubaidillah, beliau mengatakan:

“pelaksanaan tarawikh 20 roka'at ini sudah menjadi kebiasaan masyarakat mulai dulu. Mayoritas masyarakat Selokbesuki adalah warga NU, sholat tarawikh dilakukan 20 roka'at. Namun pelaksanaannya bervariasi, ada yang cepat, sedang dan pelan. Tergantung penumpang ingin menaiki kendaraan yang disukai". ${ }^{26}$

${ }^{25}$ Rahmad, Wawancara, Lumajang, 25 Mei 2016.

${ }^{26}$ Ahmad Ubaidillah, Wawancara, Lumajang, 25 Mei 2016. 
Berdasarkan hasil wawancara di atas yang peneliti lakukan di lapangan, pelaksanaan sholat Tarawih di desa Selokbesuki dimulai dengan sholat'Isya' terlebih dahulu, kemudian sholat Tarawih 20 Roka'at (2 raka'at salam), 3 Roka'at witir (yang pertama 2 Roka'at kemudian salam, kedua 1 raka'at dan salam) dan dilanjutkan membaca qunnut pada separuh akhir Ramadlan (malam 16 Ramadlan). Setelah pelaksanaan sholat Tarawih selesai, dilanjutkan dengan pembacaan al-Qur'an (tadarus).

\section{Kesimpulan}

Berdasarkan hasil penelitian yang telah paparkan di atas, maka disimpulkan bahwa Nilai/tradisi ke-Nu-an yang dilakukan masyarakat di desa Selokbesuki diantaranya adalah Tahlilan, Perayaan Maulid Nabi Muhammad SAW, Tarawih dan Qunut. Adapun pelaksanaan nilai-nilai ke-NU-an yang dilakukan masyarakat di desa Selokbesuki dirinci sebagai berikut: a) Tahlilan, dilaksanakan waktu rutinan dan ketika ada orang meninggal. Waktunya setelah Maghrib dan ada yang setelah Isya'. b) Perayaan Maulid Nabi, dilaksanakan setiap 12 Robiul Awwal, di masjid-masjid, musholla-musholla dan lembaga-lembaga pendidikan. c) Qunut Shubuh, dilaksanakan di raka'at kedua setelah I'tidal dari ruku', baik sholat berjama'ah ataupun munfarid (sendirian). d) Tarawih, dilaksanakan setelah sholat Isya' di setiap bulan Ramadlan, dengan 20 raka'at (10 salam) serta diteruskan dengan 3 raka'at witir (2 salam). Kendala-kendala dalam pelaksanaan nilai-nilai ke-NU-an adalah : a) Tahlil, Pelaksanaan kegiatan tidak sesuai dengan waktu. b) Maulid Nabi, pelaksanaannya kurang berjalan khidmad karena tempat kurang memadai, c) Qunut Shubuh, yang berjamaah di masjid dan musholla tidak begitu banyak, d) Tarawikh, masyarakat terutama para remaja sedikit malas jika terlalu sempurna mengerjakannya

\section{Referensi}

Khuluq, Lathiful. 2000. Fajar Kebangunan Ulama Biografi KH. Hasyim Asy'ari Yogyakarta: LKis.

Wahid, Salahuddin. Dkk. 2010. Menggagas NU Masa Depan Jombang: Pustaka Tebuireng.

Ali, As’ad Said. 2008. Pergolakan di Jantung Tradisi Jakarta: LP3ES.

Moesa, Ali Maschan. 2010. Memahami Nabdlatul Ulama : Urgensi Besar Membangun Kembali Jembatan Putus Surabaya: Pesantren Luhur Al-Husna.

Misrawi, Zuhairi. 2010. Hadratussyaikh Hasyim Asy'ari Moderasi, Keummatan dan Kebangsaan Jakarta: PT. Kompas Media Nusantara.

Shiddiq, Achmad. 1980. Khittah Nabdliyyah Surabaya: Balai Buku.

Wirman, Eka Putra. 2010. Kekuatan Ablussunnah Wa al-Jama'ah Jakarta: Badan Litbang dan Diklat Kementerian Agama RI.

Mahfudh, Sahal. 2004. Nuansa Fiqih Sosial Yogyakarta: LKiS. 